\title{
Winter vomiting disease caused by calicivirus
}

\author{
W. D. CUBITT ${ }^{1}$, D. A. McSWIGGAN¹, AND W. MOORE \\ From the ${ }^{1}$ Public Health Laboratory and Department of Microbiology, Central Middlesex Hospital, London, \\ and the ${ }^{2}$ Area Health Authority, Telford House, Woodside Lane, Barnet, UK
}

SUMMARY The clinical, epidemiological, and virological features of an outbreak of winter vomiting disease among London schoolchildren are described. Evidence is presented to support the view that this epidemic was caused by a human calicivirus, a virus not previously shown to be associated with this disease in man.

The term 'The Winter Vomiting Disease' was introduced 50 years ago by Zahorsky (1929) to describe what he believed to be a previously unrecognised disease. The predominant clinical features of the illness he described were vomiting, sometimes forceful, a proportion of victims also suffering abdominal cramp and diarrhoea. Symptoms rapidly disappeared, and complete recovery was the rule. The disease was highly infectious, attacking infants and young children, although adults were sometimes affected.

During the subsequent $\mathbf{4 0}$ years after Zahorsky's report, numerous outbreaks with features approximating closely to the original description have occurred (Rischel, 1935; Miller and Raven, 1936; Gray, 1939; Bradley, 1943; Reimann et al., 1945; Silverton, 1952; Webster, 1953; Clarke et al., 1972). Although a virus aetiology was strongly suspected in all these outbreaks, no virus was isolated, and in only one were transmission experiments with bacteria-free filtrates convincingly positive. More recently, however, electron microscopy has provided evidence indicating the possible association of several viruses with such outbreaks. Probably the most studied of these viruses has been the Norwalk agent, which was associated with an extensive outbreak of vomiting and diarrhoea in Norwalk, Ohio (Adler and Zickl, 1969; Thornhill et al., 1977). This agent is described as a parvo-like virus, although antigenically distinct from other parvoviruses (Greenberg et al., 1979). Several other viruses have been associated with outbreaks of winter vomiting disease or epidemic vomiting. The W (Clarke et al., 1972; Appleton et al., 1977), Harlow (Appleton and Higgins, 1975), and Ditchling agents (Appleton et al., 1977) have been incriminated in outbreaks in

Received for publication 18 December 1978 this country, and the Hawaii and Montgomery agents (Thornhill et al., 1977) in the United States. None of these agents has yet been cultured nor has any been characterised to any great extent; they are usually referred to as 'small round viruses' or 'unclassified agents' (Andrewes et al., 1978a).

In a preliminary report (McSwiggan et al., 1978), we referred to an outbreak of winter vomiting disease among London schoolchildren caused by a virus not previously associated with this disease in man. We now give in more detail the clinical, epidemiological, and virological features of that outbreak.

\section{Clinical features}

The outbreak occurred in January 1978 in an infant and junior school in north-west London. The school accommodated 235 children aged 4 to 11 years in three infant and four junior classes. There were 26 teaching and ancillary staff. The distribution of the 13 cases which occurred at the school is shown in Table 1. The class most affected was reception, which contained the youngest pupils. Nearly one-third of the children and the teacher of this class developed overt illness (Table 1). The three affected children in the higher classes were all siblings of affected children in the reception class. Only one case is known to have occurred outside the school, a 19-month-old sibling of one of the affected pupils in the reception class. After onset the number of cases built up rapidly (Fig. 1). The three children in the higher classes demonstrated symptoms 24-48 hours after their younger siblings, and the one patient outside the school became ill 48 hours after his sister. Vomiting was the most frequent clinical feature, occurring in 10 out of 14 patients; colic 
School children

Teacher
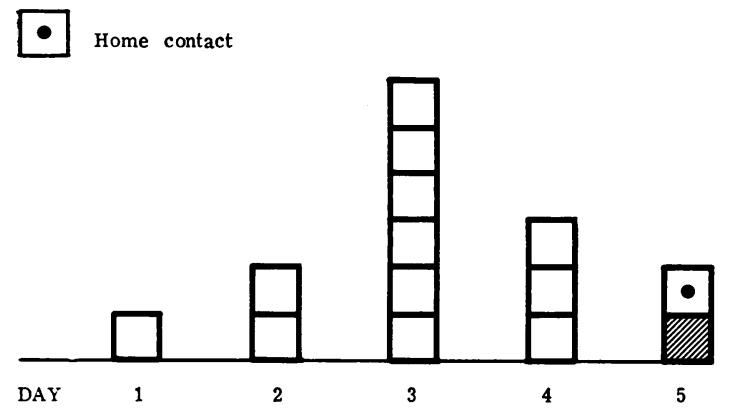

Fig. 1 Distribution of cases by day of onset.

Table 1 Distribution of illness in school

\begin{tabular}{lcc}
\hline Subjects & Total No. & No. ill \\
\hline Reception class & 37 & 9 \\
2nd year infants & 36 & - \\
3rd year infants & 36 & 1 \\
1st year junior & 35 & 2 \\
2nd-4th year junior & 91 & - \\
Teaching and ancillary staff & 26 & 1 \\
Total & 261 & 13 \\
\hline
\end{tabular}

Table 2 Clinical features in 14 cases

\begin{tabular}{ll}
\hline Vomiting & 6 \\
Vomiting and colic & 3 \\
Diarrhoea and colic & 2 \\
Diarrhoea & 2 \\
Vomiting, diarrhoea & 1 \\
and colic* & 1 \\
\hline *Adult &
\end{tabular}

*Adult

occurred in six and diarrhoea in five (Table 2). Symptoms lasted 24-72 hours, and all affected made a complete and rapid recovery.

In view of the features of the outbreak, stool samples from the first cases were examined concurrently for bacterial and viral agents. Salmonella, Shigella, and Campylobacter species and Clostridium perfringens were not detected, but the initial faecal specimens revealed calicivirus in large numbers (Fig. 2 ) in a number of the affected children. As a result of this finding, serial specimens of faeces were sought from all the affected children and from unaffected contacts for comparison. Capillary blood was collected on filter paper on at least one occasion from all those affected. Specimens were obtained from eight children between 8 and 10 days after onset of illness and further specimens from all the 14 cases four weeks later. It was not thought desirable to seek capillary blood from well children, but, in the event, several samples were taken from unaffected children in the reception class due to a misunderstanding. Venous blood was obtained from unaffected teachers and ancillary workers.

\section{Laboratory investigations}

\section{EXAMINATION OF FAECES}

(a) An emulsion of faeces was prepared in 3\% potassium phosphotungstic acid (KPTA), pH $6 \cdot 4$, and placed on a formvar carbon-coated grid; excess fluid was removed, and the grids were examined in a Phillips 201 electron microscope.

(b) A $10 \%$ suspension of faeces was made in

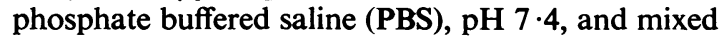
in a Rotamixer (Hook and Tucker); this emulsion was then centrifuged at $1500 \mathrm{~g}$ for 20 minutes; $0 \cdot 8$ $\mathrm{ml}$ of the supernatant was layered onto $4.0 \mathrm{ml}$ of $30 \%$ sucrose and centrifuged at $40000 \mathrm{rpm}$ for 2 hours in a SW50:1 rotor on a Beckman L5-50 centrifuge. Grids were prepared from the resulting pellet after being resuspended in a few drops of distilled water, and were then stained and examined.

\section{BUOYANT DENSITY DETERMINATIONS IN CAESIUM CHLORIDE}

Several pellets, prepared as described above, were pooled in $0.3 \mathrm{ml}$ of PBS. This suspension was layered onto $\mathrm{CsCl}$, density $1.38 \mathrm{~g} / \mathrm{l}$, and centrifuged at $40000 \mathrm{rpm}$ for 18 hours at $4^{\circ} \mathrm{C}$ in a SW50:1 rotor on a Beckman L5-50 centrifuge. Twelve fractions were collected from each gradient. The density of each fraction was determined by weighing $0.1 \mathrm{ml}$ aliquots. $20 \mu \mathrm{l}$ aliquots were removed from each fraction and placed onto $2 \%$ agarose contained in the wells of a microtitre plate. A formvar carboncoated grid was placed on the fluid and left for 1 hour to enable the $\mathrm{CsCl}$ to diffuse into the agarose. The grids were then stained with KPTA and examined for the presence of virus particles in the electron microscope.

Feline calicivirus was grown in feline lung cells until the entire cell sheet showed cytopathic effect. The cells and tissue culture fluid were harvested and pelleted in the ultracentrifuge. This material was used as a reference preparation and treated in an identical manner to the virus obtained from the faecal specimens.

\section{IMMUNE ELECTRON MICROSCOPY}

Faeces from a child collected on the first day of illness, shown to contain large numbers of single particles, was chosen as the source of antigen (Roth strain). Material prepared from this specimen, as described under (1b) above, was used as a source of antigen in all serological tests. A section measuring 




Fig. 2 Electron micrograph of virus particles in stool $($ Roth $) \times 348000$

$5 \mathrm{~mm}^{2}$ and completely covered with blood was cut out of each filter paper, and the blood was eluted in $0.1 \mathrm{ml}$ complement fixation test (CFT) buffer for 2 hours at room temperature. An equal amount of 'neat' eluate was mixed with $25 \mu \mathrm{l}$ of antigen suspension; further tests were made with doubling dilutions of the eluate, up to 1 in 8 , prepared in CFT buffer. Mixtures were placed onto $2 \%$ agarose contained in the wells of a microtitre plate, and formvar carbon-coated grids were inverted over each drop. After incubation at room temperature overnight the grids were removed from the agarose and stained with $3 \%$ KPTA and examined in the electron microscope. The serum from adults was examined neat and in doubling dilutions by the same method as that described for capillary blood; $25 \mu \mathrm{l}$ of (Roth) antigen mixed with $25 \mu \mathrm{l}$ of PBS was used as a control preparation.

ESTIMATION OF DILUTION FACTOR OF ANTIBODY FROM WHOLE BLOOD WHEN ELUTED FROM FILTER PAPER

Venous blood was dropped onto Whatman's filter paper No. 1 and allowed to dry; $5 \mathrm{~mm}^{2}$ areas covered with blood were cut out and placed in 0.1 $\mathrm{ml}$ of CFT buffer, and the blood was allowed to elute at room temperature for 2 hours. Doubling dilutions of eluate were prepared in CFT buffer, and 
$10 \mu \mathrm{l}$ aliquots were placed in the wells of a $1 \%$ agarose gel slide. Serial dilutions of the same venous blood were prepared in tubes, and $10 \mu \mathrm{l}$ aliquots were placed in wells of an agarose gel. The respective end points at which IgG could be detected in the eluate and the 'whole' venous blood were compared by allowing dilutions to diffuse towards rabbit antihuman IgG and examining the gels for the presence of precipitin lines.

\section{TISSUE CULTURE STUDIES}

Pellets prepared from faeces ( $1 \mathrm{~b})$ were resuspended in $0.5 \mathrm{ml}$ PBS, and $0.1 \mathrm{ml}$ of the suspension was inoculated into primary monkey kidney, primary baboon kidney, primary human embryo intestine, human embryo kidney, MRC5, Hep, Vero, and feline lung cell cultures. These were incubated at $35{ }^{\circ} \mathrm{C}$ on roller drums and examined daily for cytopathic effect. Cultures were maintained for three weeks through two passages. Cells and tissue culture fluid were examined by electron microscopy at each passage.

\section{ANIMAL STUDIES}

One-day-old mice were inoculated intracerebrally and subcutaneously with material prepared as for tissue culture inoculation. The mice were examined daily for $\mathbf{1 4}$ days for any signs of illness.

\section{Results}

The results of stool and antibody tests on the 14 symptomatic cases are shown in Table 3. Virus was seen in the stools of seven and antibody was detected in 13 of the 14 affected people. Three showed evidence of an increase in antibody between the first and second sera. The eluted blood was calculated to have been diluted 1 in 64 (geometric mean titre). This would be the equivalent to a titre of 1 in 128 in serum from a clotted blood specimen obtained by conventional venepuncture.

Owing to a misunderstanding, stools were obtained from three unaffected children in the reception class. In addition, stools were obtained by request from 10 other unaffected children and six teachers. These were all taken within six days of the last case showing symptoms. Virus particles were not detected in any of these specimens. (Many more specimens from unaffected children were examined and found to be negative, but these were not considered valid for control purposes for reasons stated below.)

Antibody was not detected in the capillary blood from the three unaffected children, nor in the venous blood of the six well adults.

The rate of detection of virus correlated closely
Table 3 Results of electron microscopy of stools and immune electron microscopy of sera in 14 patients

\begin{tabular}{llll}
\hline Case & $\begin{array}{l}\text { Virus particles } \\
\text { seen by EM }\end{array}$ & $\begin{array}{l}\text { Immune electron microscopy } \\
\text { on eluted sera* }\end{array}$ \\
\cline { 2 - 4 } & & NA & + Neat \\
& + & + Neat & +1 in 4 \\
& + & NA & +1 in 4 \\
$\mathbf{2}$ & + & +1 in 4 & +1 in 4 \\
3 & + & NA & +1 in 4 \\
$\mathbf{4}$ & + & NA & +1 in 4 \\
5 & + & + Neat & +1 in 4 \\
6 & + & + Neat & + Neat \\
7 & + & NA & +1 in 4 \\
8 & - & Negative & + Neat \\
9 & - & NA & + Neat \\
10 & - & +1 in 4 & +1 in 4 \\
11 & - & + Neat & + Neat \\
12 & - & Negative & Negative \\
13 & - & &
\end{tabular}

*Neat eluate $=$ serum diluted 1 in 128

NA $=$ NOT available

Table 4 Relation between time after onset of illness and ability to detect virus in stool of seven virus-positive cases

\begin{tabular}{lll}
\hline Day & No.positive & \\
\cline { 2 - 3 } & $\begin{array}{l}\text { Unconcentrated } \\
\text { specimen }\end{array}$ & $\begin{array}{l}\text { Concentrated } \\
\text { specimen }\end{array}$ \\
\hline
\end{tabular}

(a) Day after onset first specimen obtained from the 14 cases

\begin{tabular}{lll} 
(a) & Day after onset first specimen & $1 / 1$ \\
2 & $1 / 1$ & - \\
3 & - & $2 / 4$ \\
4 & $2 / 4$ & $0 / 1$ \\
5 & $0 / 1$ & $2 / 3$ \\
6 & $0 / 3$ & $2 / 3$ \\
7 & $0 / 3$ & $0 / 2$ \\
Total & $0 / 2$ & $7 / 14^{*}$ \\
(b) & * Subsequent specimens from & 7 initially positive patients \\
$>$ 6th day & $0 / 35$ & $0 / 35$ \\
\hline
\end{tabular}

with the time after onset at which the stool was obtained (Table 4). Direct examination of stools demonstrated virus in three specimens obtained within three days of the onset of symptoms. Differential centrifugation before electron microscopy revealed virus in a further four stools; however, virus particles were not detected in any specimen taken after the sixth day of onset. The rapid disappearance of virus from the stool by the sixth day was confirmed when virus could not be detected in subsequent stools from any of the seven previously positive cases.

The particle size, measured from furthest point to furthest point, showed a mean value of $30.5 \mathrm{~nm}$ (Fig. 3). Feline calicivirus was used as a reference for the measurement of size and buoyant density. The results of measurement on the feline calicivirus are in agreement with those previously established (Burroughs and Brown, 1974; Love and Jones, 1974). The distinct morphology of the virus particle, when 


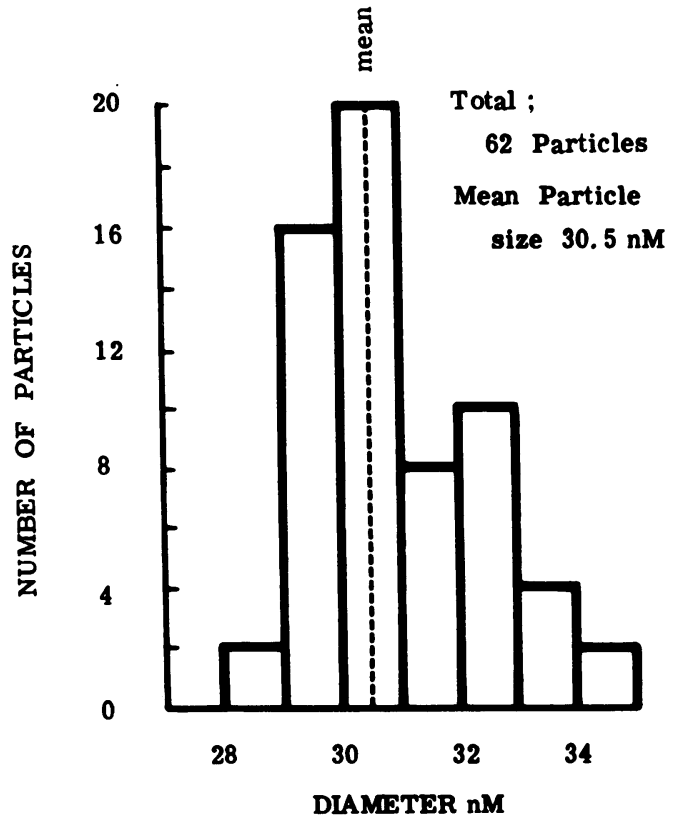

HUMAN

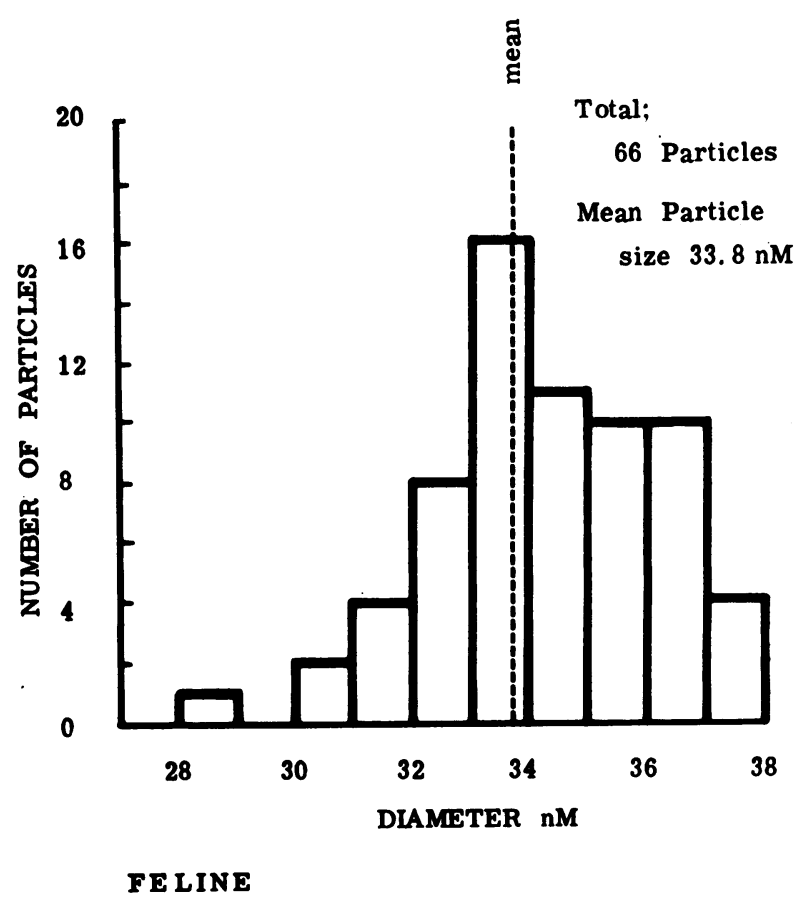

FE LINE

Fig. 3 Histogram showing distribution and mean of particle size of human and feline calicivirus.

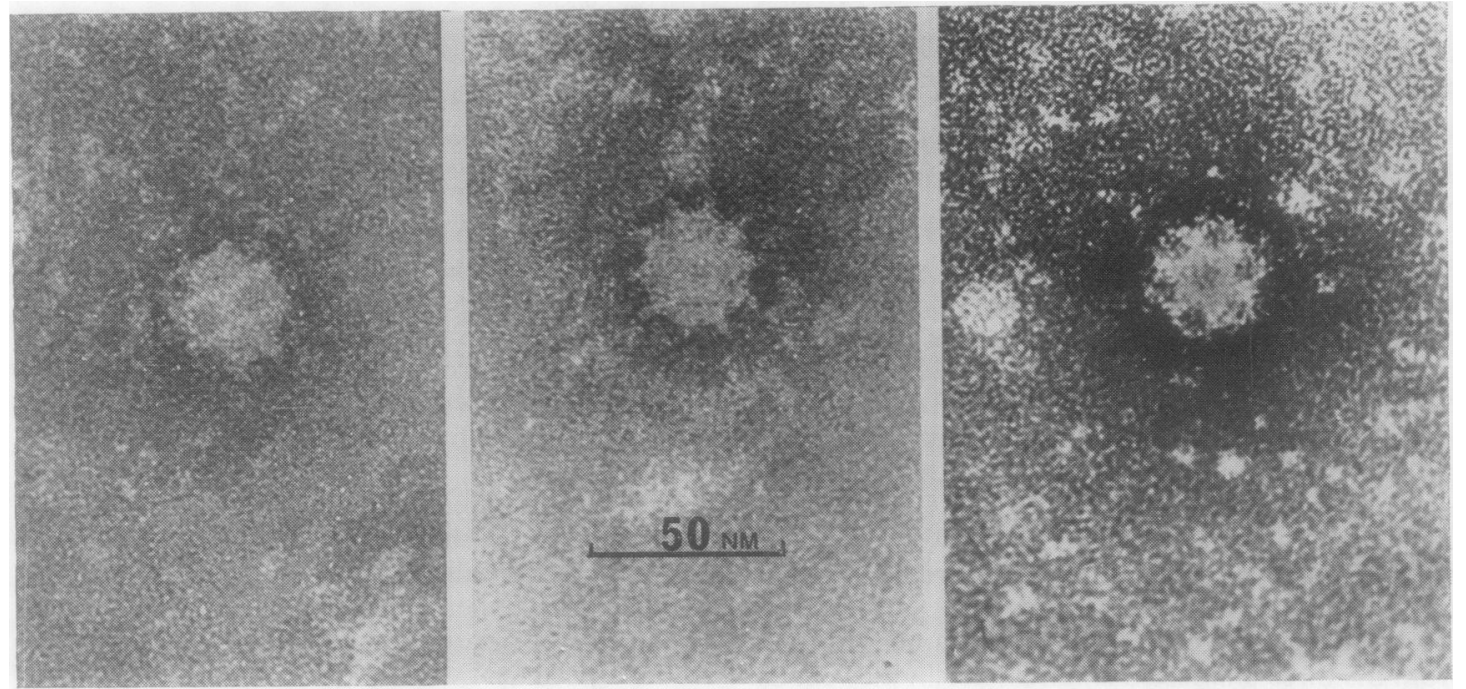

Fig. 4 Electron micrograph showing virus morphology when viewed along the two-fold axis (square cross), five-fold axis (ten spiked sphere), and three-fold axis (Star of David) $\times 410500$ 

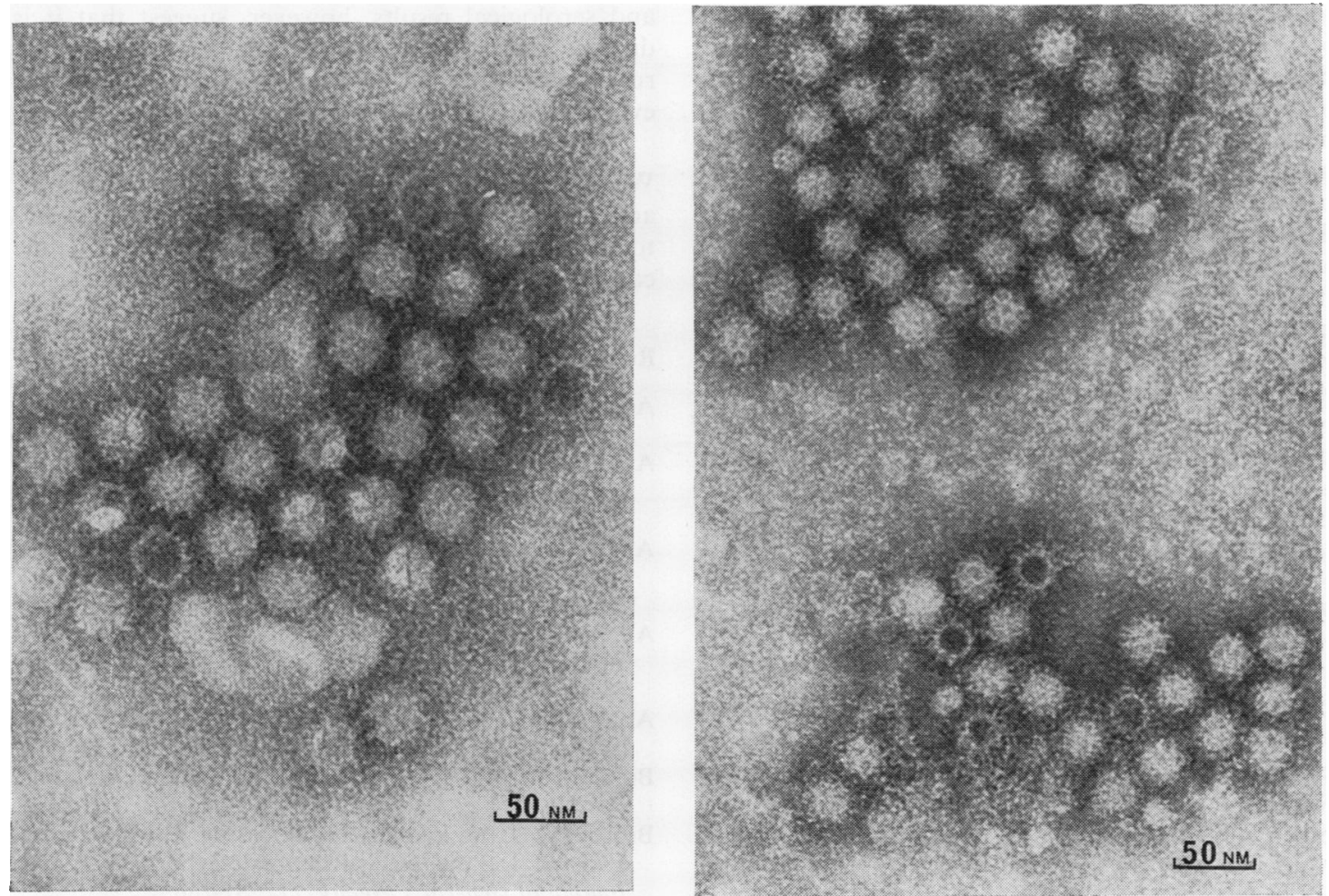

Fig. 5 Electron micrograph of human (right) $\times 183000$ and feline $($ left $) \times 203500$ calicivirus aggregated by homologous antibody.

viewed along the two-fold, three-fold, and five-fold axes of symmetry, is clearly shown (Fig. 4). The three particles shown are all taken from one stool sample; similar particles were seen in all the other positive specimens. We have not so far been able to demonstrate evidence of viral replication in any of the cell culture systems tested or to show any effect on day-old mice.

\section{Discussion}

The clinical and epidemiological features of the illness in the London schoolchildren correspond closely with the original description of winter vomiting disease (Zahorsky, 1929). Although the mode of transmission is not apparent, the distribution of cases among the youngest children in the school and the very limited spread (one case) to home contacts, might be taken as evidence of widespread acquisition of immunity to the causal agent shortly after the age of school entry. Only two of the 12 affected schoolchildren had younger siblings; one of these two was the affected home contact. As the virus has not yet been grown in tissue culture, insufficient antigen is at present available to allow investigation of the antibody status of the various age groups. This problem may be circumvented if it can be shown that animal calicivirus antigen can be used to test human sera, but this has not yet been established. Immunity in the older group is not necessarily the only explanation for the age-related distribution in this school outbreak. Shigella dysentery is more common in younger schoolchildren owing to their lower personal hygiene, particularly in relation to handwashing after defaecation. A similar mechanism might have influenced the age-related epidemiological pattern of spread in this outbreak.

It has been pointed out that the availability of electron microscopy for clinical investigations has resulted in an 'embarras de richesses' (Flewett, 1976) in terms of putative aetiological viruses in gastrointestinal infections. A number of criteria have therefore been proposed (Patterson et al., 1975; Flewett, 1976), which should be satisfied before an agent detected by electron microscopy is accepted as the cause of a particular disease. These criteria have been sufficiently satisfied in this instance to justify the claim that the virus demonstrated was the 
cause of the illness described. Its presence at the time of symptoms, and rapid disappearance thereafter, have already been referred to; indeed, this may be one reason why it has not been detected in earlier outbreaks of winter vomiting disease. On the other hand, the virus was not seen in those in the same population who were not ill. Similarly, antibody was detected (and, in several cases, shown to rise) at the appropriate time in all but one of those affected (the only adult with symptoms) and was not detected in any unaffected person. The use of capillary blood with an unavoidably high dilution factor (due to elution) proved satisfactory in this instance. Antibody determinations subsequently on venous blood specimens from three of the children with 'eluted' antibody titres confirmed the accuracy of the dilution factor calculations. Feeding experiments in volunteers (in conjunction with Dr S. E. Reed) and in chimpanzees (in conjuction with Professor A. J. Zuckerman) are being arranged, and the results will be reported.

Caliciviruses (Andrewes et al., 1978b) are well known animal pathogens; indeed, the prototype virus, vesicular exanthema virus, is classified as a category A pathogen (Department of Health and Social Security, 1975). They have not, however, previously been shown to cause disease in man. Madeley and Cosgrove (1976) reported finding 'apparently typical' caliciviruses in the stools of 10 children during a survey in Glasgow. Although these workers were, however, unable to give any significance to the presence of these viruses, the finding of calicivirus in the small bowel of an infant who had died from gastroenteritis (Flewett and Davies, 1976) indicated a possible association with human disease. These workers also reported caliciviruses in the stools of a child with gastroenteritis. However, on this occasion adenoviruses were also present in large numbers. We believe that the agent causing the outbreak of winter vomiting disease in the London schoolchildren is a human calicivirus. The particle size and buoyant density are consistent with this conclusion, although these features are compatible with several other small viruses, for example, parvoviruses and some 'small round' viruses. Caliciviruses, however, have a very distinctive morphology, demonstrating cuplike depressions (calex $=$ cup) on their surface and presenting three characteristic forms, depending on whether the virus is visualised along its two-fold, three-fold, or five-fold axes of symmetry (Burroughs et al., 1978). The agent we have identified demonstrates the size and very distinctive morphology of the Caliciviridae, which strongly suggests that it is a member of this group. (A feline calicivirus is shown for comparison with the human strain (Fig. 5).) Preliminary cultural and serological results, however, suggest that it is distinct from the three established animal caliciviruses and likely to be of human origin. Further evidence for this is being prepared.

We are indebted to the headmaster, staff, parents, and pupils of the school for their cooperation, and to Wellcome Research, who supplied the feline calicivirus and reagents.

\section{References}

Adler, J. L., and Zickl, R. (1969). Winter vomiting disease. Journal of Infectious Diseases, 119, 668-673.

Andrewes, C. H., Pereira, H. G., and Wildy, P. (Eds) (1978a). Viruses of Vertebrates, 4th edition, pp. 401-402. Bailliere Tindall, London.

Andrewes, C. H., Pereira, H. G., and Wildy, P. (Eds) (1978b). Viruses of Vertebrates, 4th edition, pp. 38-41. Baillierre Tindall, London.

Appleton, H., Buckley, M., Thom, B. T., Cotton, J. L., and Henderson, S. (1977). Virus-like particles in winter vomiting disease. Lancet, 1, 409-411.

Appleton, H., and Higgins, P. G. (1975). Viruses and gastroenteritis in infants (Letter). Lancet, 1, 1297.

Bradley, W. H. (1943). Epidemic nausea and vomiting. British Medical Journal, 1, 309-312.

Burroughs, J. N., and Brown, F. (1974). Physiochemical evidence for the reclassification of the caliciviruses. Journal of Generai Virology, 22, 281-286.

Burroughs, J. N., Doel, T. R., Smale, C. J., and Brown, F. (1978). A model for vesicular exanthema virus, the prototype of the calicivirus group. Journal of General Virology, 40, 161-174.

Clarke, S. K. R., Cook, G. T., Egglestone, S. I., Hall, T. S., Miller, D. L., Reed, S. E., Rubenstein, D.. Smith, A. J., and Tyrell, D. A. J. (1972). A virus from epidemic vomiting disease. British Medical Journal, 3, 86-89.

Department of Health and Social Security (1975). Report of the Working Party on Laboratory Use of Dangerous Pathogens (Chairman: Sir G. Godber). Cmnd 6054. HMSO, London.

Flewett, T. H. (1976). Implications of recent virological researches. In Acute Diarrhoea in Childhood (Ciba Foundation Symposia New Series, No. 42), 237-249. Excerpta Medica, London.

Flewett, T. H., and Davies, H. (1976). Caliciviruses in man (Letter). Lancet, 1, 311

Gray, J. D. (1939). Epidemic nausea and vomiting. British Medical Journal, 1, 209-211.

Greenberg, H. B., Wyatt, R. G., Valdesuso, J., Kalica, A. R., London, W. T., Chanock, R. M., and Kapikian, A. Z. (1978). Solidphase micro-titre radio-immunoassay for detection of the Norwalk strain of acute non bacterial, epidemic gastroenteritis virus and its antibodies. Journal of Medical Virology, 2, 97-108.

Love, D. N., and Jones, R. F. (1974). Studies on the buoyant density of a feline calicivirus. Archiv für die gesamte Virusforschung, 44, 142-143. 
McSwiggan, D. A., Cubitt, W. D., and Moore, W. (1978). Calicivirus associated with winter vomiting disease (Letter). Lancet, 1, 1215.

Madeley, C. R., and Cosgrove, B. P. (1976). Caliciviruses in man (Letter). Lancet, 1, 199-200.

Miller, R., and Raven, M. (1936). Epidemic nausea and vomiting. British Medical Journal, 1, 1242-1244.

Patterson, S., Parry, J., Matthews, T. H. J., Dourmashkin, R. R., Tyrrell, D. A. J., Whitehead, R. G., and Rowland, M. G. M. (1975). Viruses and gastroenteritis (Letter). Lancet, 2, 451.

Reimann, H. A., Hodges, J. H., and Price, A. H. (1945). Epidemic diarrhea, nausea and vomiting of unknown cause. Journal of the American Medical Association, 127, 1-6.

Rischel, A. (1935). Epidemic nausea? (Norwegian). Ugeskrift for Laeger, 97, 1285-1288.
Silverton, M. I. (1952). An outbreak of illness at Rye Grammar School. Medical Officer, 88, 215.

Thornhill, T. S., Wyatt, R. G., Kalica, A. R., Dolin, R., Chanock, R. M., and Kapikian, A. Z. (1977). Detection by immune electron microscopy of 26-to 27-nm viruslike particles associated with two family outbreaks of gastroenteritis. Journal of Infectious Diseases, 135, 20-27.

Webster, R. C. (1953). A large outbreak of epidemic vomiting. Medical Officer, 90, 39-40.

Zahorsky, J. (1929). Hyperemesis hiemis or the winter vomiting disease. Archives of Paediatrics, 46, 391-395.

Requests for reprints to: Dr D. A. McSwiggan, Public Health Laboratory, Department of Microbiology, Central Middlesex Hospital, Park Royal, London NW10 7NS, UK. 
Another well-written chapter is by W. D. and J. E. Edwards on pulmonary vasculature, particularly the description of plexogenic pulmonary arteriopathy. L. Reid has brought us up to date with research on mucus secretion in the lung.

The monograph should interest anyone concerned with teaching pulmonary pathology or wanting to learn about it.

BRIAN E. HEARD

Clinical Gastrointestinal Immunology. By H. C. Thomas and D. P. Jewell. (Pp. viii +264 ; illustrated; $£ 12 \cdot 00$.) Oxford: Blackwell Scientific Publications. 1979.

In the past 10-15 years both basic and applied immunology have produced an 'explosion' (as the authors state) not only in gastroenterology but in most of the clinical specialties; with the probable exception of nephrology, however, gastroenterology represents the specialty in which both basic and applied immunology have contributed most to our understanding. This is borne out by the number of texts which have now appeared and continue to appear dealing with various aspects of the immunology of the gastrointestinal tract and liver. The need for a further monograph such as the present one is in no doubt; it provides a most lucid and concise 'up-date' of current knowledge and with a judicious and careful critical approach in those areas where the evidence as yet remains equivocal.

The first three chapters provide a basic immunological background against which the subsequent chapters are set. One wonders whether the authors have not been a little patronising in assuming that their colleague gastroenterologists have not as yet become sufficiently familiar with the language and concepts of immunology; if they have not, then it is surely an indictment of our undergraduate and postgraduate medical education. If there is need to include a glossary in which, for example, gluten and reticuloendothelial system appears, are they justified in assuming a sufficient virological knowledge among their readers to be able to understand nucleocapsid, DNA polymerase, and others? Having said this, however, these three chapters represent an excellent precis of current knowledge, and for any gastroenterologist who has missed out on his immunology the book is worth purchase for this alone. The subsequent chapters deal with particular diseases, including intestinal and hepatic infections (perhaps the least satisfying in its rather sketchy and brief handling of the topic), coeliac disease, chronic inflammatory bowel diseases, acute and chronic hepatitis, and others. There are some minor inconsistencies here and there, for example, in a balanced review of Crohn's disease and ulcerative colitis immune responsiveness in the former becomes immunological competence in the latter. The chapter on acute and chronic viral hepatitis is a masterpiece, in which the complexities of the host/viral interrelationships are clearly and skilfully outlined. The authors are to be congratulated on this excellent text, and it is a pleasure to commend it.

R. N. M. MACSWEEN

Post Mortem Procedures. (An Illustrated Textbook). By G. A. Gresham and A. F. Turner. (Pp. 160; illustrated; £8.00.) London: Wolfe Medical Publications Ltd. 1979.

Sex and violence pervade the media and intrude into this book. The first page advises us that sexual intercourse is a cause of sudden death, and the later chapters are full of high-quality gruesome photographs of the mutilated victims of violence. This type of presentation, with a tabloid-type format of numerous photographs (thankfully in monochrome) and a concise text in short, easily read sentences, may attract a mortuary technician with limited literary horizons.

To a hospital pathologist trying to raise the standards of his postmortem room the 60 pages on the technique of the postmortem examination are outstanding. The step-by-step illustrations of how to remove the organs are excellent, and most of them speak for themselves. Specialised techniques and mortuary administration are also described, and pathologists in training will benefit from a quick perusal of this book. It is well-printed on good paper, does not take long to read, and is not expensive. Recommended for the mortuary staff to read and to imitate. The pathologist who works with technicians who can reproduce these procedures is fortunate.

R. A. B. DRURY

\section{Corrections}

A new technique for Gram staining paraffin-embedded tissue by $K$. ENGBAEK, $K$. $s$. JOHANSEN, and M. E. JENSEN (Journal of Clinical Pathology, 1979, 32, 187-190.)

On page 188 , column 1 , paragraph 2 , line 7, under solution (C) should be added: 'Working Solution: stock solution $10 \mathrm{ml}$, distilled water $50 \mathrm{ml}$.'

Winter vomiting disease caused by calicivirus by W. D. CUBITT, D. A. MCSWIGGAN, and W. MOORE (Journal of Clinical Pathology, 1979, 32, 786-793).

Results:

Buoyant density in $\mathrm{CsCl}$

Feline calicivirus $1 \cdot 36-1 \cdot 42 \mathrm{~g} / \mathrm{cm}^{-3}$

'Human' calicivirus $1 \cdot 36-1 \cdot 38 \mathrm{~g} / \mathrm{cm}^{-3}$ 